\title{
Assessment of Socio-Economic Impacts of Zeolite Mining to Regional Development - Case Study
}

\author{
Zuzana Šimková ${ }^{1, *}$, Milan Grohol ${ }^{1}$, Krysztof Kubacki ${ }^{1}$, and Martin Kapko ${ }^{1}$ \\ ${ }^{1}$ Institute of Earth Resources, Faculty of Mining, Ecology, Process Control and Geotechnologies, \\ Park Komenského 19, 042000 Košice, Slovakia
}

\begin{abstract}
The presented article deals with the impact of mining of mineral resources, namely zeolites, to the socio - economic area of regional development. Case study is focused on analysis of macroeconomic parameters of selected indicators for the implementation of the zeolite mining project in the Prešov region. This way we can point out to benefits for the state and the region. In accordance with the applicable legislation are quantified revenues for the municipality (or region) - the form of payments for the mining area, extracted minerals and local taxes and fees, for the state in the form of levies and taxes on employment, corporate income tax, VAT. In conclusion, it summarizes and quantifies the economic benefits of zeolite mining for the state and the investor through the duration of the surface mining of the mineral resource.
\end{abstract}

\section{Introduction}

The important components of raw material resources in the Slovak Republic are nonmetallic raw materials, including zeolite deposits. Mining and utilization of zeolites is directly determined by the development of demand on market and by their specific characteristics, which are $[1,2]$ :

- high ion exchange and selectivity,

- reversible hydration and dehydration,

- high gas sorption capability,

- high thermostability,

- resistance to aggressive environments,

Thanks to the abovementioned specific physico-chemical properties, the zeolite has widely use in various national economic sectors of the Slovak Republic, e.g. in agricultural and livestock production, building industry, water and flue gas cleaning, heavy metal removal from water, moisture reduction, also in various other industries $[2,3]$. Despite these facts, it is necessary to be the zeolite deposits effectively exploited to achieve the desired economic, social, and environmental impact in terms of sustainable development of the Slovak Republic regions [4, 5]. Sustainable development of Slovak Republic regions with an effective way of exploiting zeolite deposits can be understood as a strategic,

\footnotetext{
* Corresponding author: zuzana.simkova@tuke.sk
} 
complex and synergic process affecting the economic - social and environmental aspects, which minimizes interventions which threatening, damaging, resp. devastating living conditions, adequately exploits raw material resources and protects the Slovak cultural and natural heritage $[6,7]$.

\section{General characteristics of zeolite deposit in Prešov region}

Analyzed area of the zeolite deposit is located in the village of Kučín, in the Vranov nad Toplou district in the Prešov region. The utility material of the Kučín deposit is zeolite ryodacite tuff, with clinoptilolite in dispersed form throughout the mass of rock. The average clinoptilolite content of the deposit is $49.80 \%$. The overall parameters of the volume of exploitable reserves with regard to mining and technical conditions, environmental and economic conditions were considered as follows:

- total geological reserves: 17392 ths. t,

- state of reserves:

- free balance reserves: $17064463 \mathrm{t}$,

- not balance reserves: $328000 \mathrm{t}$.

\section{Analysis of socio-economic impact of zeolite mining}

Determination of economic effectiveness of financial investment of mining and processing technology to the deposit of zeolite was made according evaluation of investment effectiveness. We evaluated the project to 12 years with condition that in first year mining will be $1500 \mathrm{t}$, in $2 \mathrm{nd}$ year $-5000 \mathrm{t}$, in 3 rd year $10000 \mathrm{t}$, in 4th year $15000 \mathrm{t}$, in 5th-12th year $20000 \mathrm{t}$.

For evaluation of zeolite extraction in mining space Kučín and for social and economic evaluation of the project, there is necessary to evaluate total economic situation of the project. This consists of project investment costs, fixed and variable costs, known in time of project evaluation, assumed revenues, etc. In summary it means project evaluation for zeolite deposit using.

To project start-up there is necessary investment - 1 mil. Eur. ( $50 \%$ own sources). For successful realization of the project there is necessary to invest financial means - debt - 1 mil. Eur in time horizon 8 years. Production costs are determined according assumed production capacity of the deposit in Kučín. At the determination of unit production costs there is necessary to state also measure of the costs actualization. Measure of actualization was determined with regard to the market of consumption materials and energy as follows: in first three years measure of actualization is determined at level $9 \%$, which presents measure of growth of market prices. This will be influenced also by inclusion to the common EU market, where there is assumed considerable growth of input prices according territorial influence of produced volume and actual consumption of inputs in subject territory. Following measure of actualization is determined at value $6 \%$.

For evaluation there is considered with production costs in volume 18.25Eur.t. ${ }^{-1}$, since from original value wage costs had been excluded in volume 6.6 Eur.t $\mathrm{t}^{-1}$. Wage costs are in evaluation of raw material deposits calculated individually.

With regard to the annual production direct production costs are determined according higher mentioned at value: 18.25 Eur. $\mathrm{t}^{-1}$ of extraction material. Average unit sale price of extracted zeolite had been determined at level 59.75 Eur.t- $^{1}$ with regard to the previous development. 


\subsection{Cash-Flow (CF) development}

Summary CF has increasing trend and during whole period of project operation for deposit extraction it is over zero. It means index without regard to time actualization, while present value of zeolite deposit (PV) presents 5795871 Eur.

\subsection{Value of deposits at the locality (net present value NPV)}

Value of zeolite deposit in mining space Kučín, defined by mentioned research area, evaluated time horizon of extraction to 12 years, capacity of zeolite extraction, used by the project and according measure of actualization from 2010, period of investment termination, is determined at level 2184958 Eur.

\subsection{Payment of mining space}

Among region income from the evaluated project belongs payment for mining space. Payment for mining space is in volume $80 \%$ of village income and $20 \%$ income to state budget. Since mining company till present time does not have given mining space, there is not possible to calculate this level. In considering area of mining space, income to state budget from mining space extraction means value 166 Eur. year ${ }^{-1}$, which means during 12 years 1992 Eur.

\subsection{Payment for the extracted mineral}

Value of payment for the extracted mineral is calculated according conditions, given by NV SR č. 50/2002 Z. z. about payment for the extracted mineral, payment for mining space and payment for gas stocking and liquid stocking as amended. The rate of payment for the extracted minerals from the view of zeolite means $4 \%$. Total volume of payment for the extracted minerals during the project realization presents sum: 457685 Eur.

\subsection{Local taxes and fees}

Next income for the region, resp. village is income from property tax. This taxi s calculated according actual General decree in Kučín VZN.

\subsection{Wages, incomes to state budget and payroll taxes}

Total average price of work during project realization is created by gross wage of the employees, employee's fee and employer's fee, which present 2 149,67 Eur.month ${ }^{-1}$ (super gross wage), presenting total level of fees that is paid by employer - 559.67 Eur.month ${ }^{-1}$, while at considering number - 15 employees and time of realization - 12 years, the total fees will be 1208 887,2 Eur. State income from employees and employer fees is presented by fees to social security in level $35.2 \%$ from super gross wage of employee that is paid by employer and $13.4 \%$ gross wage of employee that is paid by employee himself. At the same time employee pays 19\% payroll tax from gross wage. At the average monthly wage 1590 Eur.month $^{-1}$ payroll tax presents 200.97 Eur.month $^{-1}$.

Total average annual state income, presented by payments from employer and employees, and payroll taxes presents 175266 Eur in considered 15 employees. 


\subsection{Income of state by the way of income tax}

Tax of legal entity depends on the volume of investment, calculated monthly tax deductible costs, depreciations and total revenues. During time of project realization there is assumed mining company will pay income tax in level: 2264169 Eur.

\subsection{Income of the state as value added tax (VAT)}

Value added taxi s one of the indirect taxes that present state income. If the difference between taxable trade and deduction of tax is possible, it means tax to pay - income for the state. If this difference is negative, it means excessive deduction of tax - state will give back the volume of excessive deduction. According level of achieved turnover in previous tax period tax subject is quarterly or monthly payer of value added tax. Total assumed state income from the project realization as value added tax presents 2173015 Eur.

\subsection{Assessment of socio - economic impacts to development of Prešov region}

From the results of detail quantitative analysis we can state that project of zeolite extraction in Prešov region there will be provided 15 new working posts, while predicted income from the project realization for potential investor could be approximately 2184958 Eur with total investment costs in level approximately 987851 Eur and total costs in level approximately 8018844 Eur. From the predicted quantification of total incomes we found that these will present approximately 17811790 Eur for potential investor during assumed chronological duration of the project (Table 1).

Table 1. Summary of economic indexes of zeolite extraction in Prešov region for the investor.

\begin{tabular}{|c|c|c|c|}
\hline Economic indexes & $\begin{array}{c}\text { Average annual value } \\
{[\text { Eur] }}\end{array}$ & Period & $\begin{array}{c}\text { Sum } \\
{[\text { Eur] }}\end{array}$ \\
\hline Total investment costs & - & $0-1$ year & 987851 \\
\hline Total costs & 42150 & Project & 8018844 \\
\hline Total incomes & 66300 & Project & 17811790 \\
\hline Net profit & - & Project & 5795871 \\
\hline $\begin{array}{c}\text { NPV for investors from } \\
\text { project realization }\end{array}$ & - & Project & 2184958 \\
\hline
\end{tabular}

Total predicted state income from the zeolite extraction in Prešov region will present approximately 7000053 Eur, while payment for mining space during planed mining -12 years will be in level 1992 Eur and payment for extracted minerals will be 457685 Eur. Income state by the way of income tax from legal entity presents during 12 years of project realization approximately 57956 Eur and by value added tax it will be approximately 74000 Eur (Table 2Table ).

Table 2. Summary of economic indexes of zeolite extraction in Prešov region for the state.

\begin{tabular}{|c|c|c|c|}
\hline Economic indexes & $\begin{array}{c}\text { Average annual value } \\
{[\text { Eur] }}\end{array}$ & Period & $\begin{array}{c}\text { Sum } \\
{[\text { [Eur] }}\end{array}$ \\
\hline Payment for mining space & 166 & 12 years & 1992 \\
\hline $\begin{array}{c}\text { Payment for extracted } \\
\text { mineral }\end{array}$ & 38140 & Project & 457685 \\
\hline $\begin{array}{c}\text { Income to state budget } \\
\text { from levies and payroll }\end{array}$ & 175266 & Project & 2103192 \\
\hline
\end{tabular}




\begin{tabular}{|c|c|c|c|}
\hline taxes & & & \\
\hline State income as VAT & 181084 & Project & 2173015 \\
\hline State income as income tax & 188680 & Project & 2264169 \\
\hline $\begin{array}{c}\text { State income from project } \\
\text { realization together [Eur] }\end{array}$ & & 7000053 \\
\hline
\end{tabular}

\section{Conclusion}

Despite the fact that mining in the eyes of the general public is many times a negative phenomenon, it generally brings a positive socio-economic impact, not only for region where the deposit is located, but also for the state as a whole.

This is also pointed out in the submitted and elaborated article, which points to the economic impact on the Prešov region at a particular deposit - Kučín. Not only the deposit and its extraction contribute by economic value in the form of income for the region and the state, but it will also indirectly contribute to raising the social level and improving the quality of life for its inhabitants. On the one hand, jobs will be created, which in turn will increase the region's purchasing power, which in turn will have a positive effect on trade and services. This is only one a positive side, which was described, because all the raw materials extracted are part of our everyday life in the form of individual things, components, or even a necessity for the using of renewable raw materials (instrument basis).

Contribution is partial result of projects solving VEGA MŠVVaŠ SR 1/0515/18 „The decisionmaking model of process of evaluating raw material policy of regions".

\section{References}

1. S. Khouri, H. Pavolová, M. Cehlár, T. Bakalár, Metalurgija, 55, 3 (2016)

2. T. Bakalar, H. Pavolova, M. Kanuchova, Chem. Listy, 111, 4 (2017)

3. H. Pavolová, A. Csikósová, T. Bakalár, Appl. Mech. Mater., 209-211 (2012)

4. S. Khouri, M. Cehlár, K. Horanský, K. Šándorová, Transform. Bus. Econ., 16, 2 B (2017)

5. P. Taus, J. Kosco, R. Rybar, D. Kudelas, SGEM 2011, 3 (STEF92 Technology Ltd., Albena, 2011)

6. H. Pavolová, T. Bakalár, E. M. A. Emhemed, Z. Hajduová, M. Pafčo, Entrepreneurship Sustainability Issues, 6, 3 (2019)

7. H. Pavolová, A. Csikósová, K. Čulkova, M. Antošová, Maria, Appl. Mech. Mater., 152, 154 (2012) 